\title{
Diversity Study of Wood Rotting Fungi from Two different Forests in Mizoram, India
}

\author{
Josiah M.C. Vabeikhokhei ${ }^{1}$, Zohmangaiha ${ }^{1}$, John Zothanzama $^{1^{*}}$ and H. Lalrinawmi ${ }^{1}$ \\ ${ }^{1}$ Department of Environmental Science, Mizoram University, Aizawl 796004, Mizoram, India \\ *Corresponding author
}

\begin{abstract}
A B S T R A C T
Keywords

Ascomycota, Basidiomycota, Mizoram, Wood rotting fungi

Article Info

Accepted:

20 March 2019

Available Online:

10 April 2019

A three years (2015-2017) study was carried out to study the diversity of Wood Rotting Fungi from two different forest stands, Hmuifang forest and Tanhril forest of Mizoram, Northeast India. A total of 45 species were identified from both the study sites. It was observed that a total of 21 species were common to both the forests whereas 19 species were found only found in Hmuifang forest and 5 species only in Tanhril forest. ShannonWiener's diversity index of fungal species was found to be 3.31 in Hmuifang forest and 2.99 in Tanhril forest; Simpson shows 0.95 in Hmuifang and 0.90 Tanhril forest; Menhinick's index shows 1.91 for Hmuifang and 1.22 in Tanhril forest; Margelef's index shows 6.41 in Hmuifang and 3.98 in Tanhril forest; Pielou's eveness index shows 0.54 in Hmuifang and 0.51 in Tanhril forest. However, the species diversity of wood rotting fungi was higher in Hmuifang forest than compared to Tanhril forest which may be due to higher altitude, low temperature, high relative humidity, soil moisture content and experiences higher amount of rainfall annually which in turn have a great impact on the type of vegetation.
\end{abstract}

\section{Introduction}

Mizoram is one of the seven sister States in North East India. It lies in the extreme eastern corner of the country and shares its borders with Assam, Manipur and Tripura and has very long international borders with Myanmar and Bangladesh. The state has a geographical area of $21,087 \mathrm{sq} . \mathrm{km}$. and lies between $21^{\circ} 56^{\prime}$ and $24^{\circ} 35^{\prime} \mathrm{N}$ Latitudes and $92^{\circ} 16^{\prime}$ and $93^{\circ} 26^{\prime}$ E Longitudes. The Tropic of Cancer passes through the State at $23^{\circ} 30^{\prime}$ N latitude. Woodrotting fungi are one of the most important parts of forest ecosystem, and play an important role in degrading the wood in forest ecosystem. The major species of these fungi include the groups of Aphyllophorales (Basidiomycota), Discomycetes (Ascomycota) and some imperfect fungi. They have the ability to degrade cellulose, hemicelluloses and lignin of wood. Three type of wood decaying have been found, i.e., white rot, brown rot and soft rot. Many other organisms of forest ecosystem have symbiosis relationship with wood rotting fungi. Wood rotting fungi could offer the nutrition for 
many insects and birds, and spores of many wood rotting species are spread by some insects. The rich diversity of wood rotting fungi is one of the important factors for the functioning of forest ecosystem.

Wood-rotting fungal communities are typically species-rich, and include multiple decomposer species in the same wood substrate. Throughout the decomposition of a fallen tree, fungal species interact with each other as community composition develops over time. The resident fungi must either defend an occupied domain or replace the mycelia of primary established species (Ottosson, 2013). As the main agents of wood decay, fungi can be considered as ecosystem engineers (Lonsdale et al., 2008).

Only about $6.7 \%$ of 1.5 million species of fungi estimated in the world have been described and most of these are in temperate regions. The tropical region which is undoubtedly hosting the highest mycodiversity has been inadequately sampled and the mycoflora scarcely documented (Hawksworth, 2001). This makes the situation of macrofungi in the tropical forests unclear (Hawksworth, 2004). However new species are still being identified in the tropics (Douanla-Meli et al., 2007).

(Zothanmawia et al., 2016) identified 15 species of wood rotting fungi from Pachhunga University College Campus. (Zothanzama, 2011) identified a total of 53 species of wood rotting fungi from different forest stands in the districts of Aizawl, Mamit, Kolasib, Champhai and Saiha of Mizoram during the period of 2006-2010. (Bisht, 2011) in his book Wood Decaying Fungi of Mizoram also described 52 species collected from different parts of the state. (Zothanzama et al., 2017) also identified a new species of wood rotting fungi from Mizoram Ganoderma mizoramense. The current study highlights the diversity framework of wood rotting fungi from a protected forest (Hmuifang) and a disturbed forest (Tanhril).

\section{Materials and Methods}

\section{Study sites}

\section{Hmuifang}

The study area is situated in the southern part of Aizawl. It is about $50 \mathrm{~km}$ away from the state capital Aizawl with an average elevation of 1619 amsl. The survey area lies between the coordinates $23^{\circ} 27^{\prime} 22^{\prime \prime} \mathrm{N}-23^{\circ} 27^{\prime} 31^{\prime \prime} \mathrm{N}$ latitudes and 92 $45^{\prime} 19^{\prime \prime} \mathrm{E}-92^{\circ} 45^{\prime} 24^{\prime \prime} \mathrm{E}$ longitudes. The mountain area is still covered with virgin forests. The vegetations of the study area fall under Tropical semi-evergreen forests. The average annual rainfall is about $267.13 \mathrm{~mm}$. The temperature ranges from $20^{\circ} \mathrm{C}-29^{\circ} \mathrm{C}$ during summer and winter temperature ranges from $7^{\circ} \mathrm{C}-21^{\circ} \mathrm{C}$ (Source: State Meteorological Centre, DST, Mizoram).

\section{Tanhril forest}

The sample collection was carried out at Tanhril Forest within Mizoram University Campus located on the south-western part of Aizawl city, the Capital of Mizoram which is $15 \mathrm{kms}$ away from the capital and lies between 230.42 ' to $230.46^{\prime} \mathrm{N}$ latitude and $920.38^{\prime}$ to $920.42^{\prime} \mathrm{E}$ longitude and located at an altitude of 850 metres amsl with an average rainfall of $230 \mathrm{~mm}$. (Source: State Meteorological Centre, DST, Mizoram).

\section{Sampling, collection and preservation of specimens}

The specimens were collected randomly since there are no standard methods for accurately estimating the macrofungal species richness of an area based on a sample of the macrofungi (Schmit et al., 1999). 


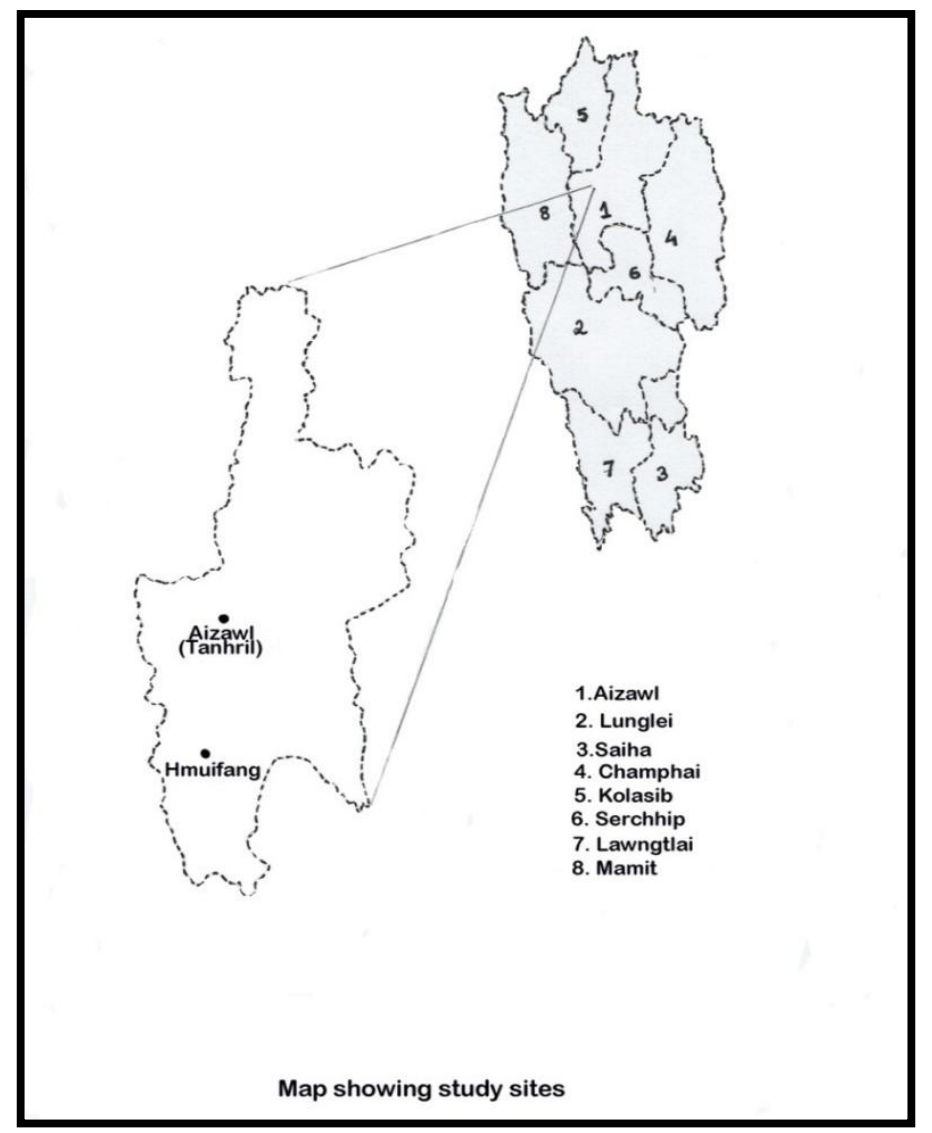

This is due to chances of occurrence of the fungal specimen. The number of individual specimen was recorded in both the sites. The collection periods are divided into two seasons (Rainy season from April to September and Dry season from October to March).

The samples were collected or isolated from its substrates or host (dried wood/branches) with the help of knife or other sharp materials and sometimes simply plucked with bare hand (in case of soft samples). Samples collected were kept in air-tight container or plastics bags which are labeled after collection. Photograph of each sample collected were taken in the field and in the laboratory (Prasher, 2015; Zothanzama, 2011).

The specimens are preserved by air drying, deep freezing and liquid preservation (Meenakshisundaram and Bharathiraja, 2013;
Zothanzama and Lalrinawmi, 2015). Voucher numbers are given to the specimens and stored in the Department of Environmental Science, Mizoram University.

\section{Identification of specimens}

The collected specimens were identified according to standard macroscopic and microscopic characteristics through consultation with appropriate literature (Gilbertsonand Ryvarden, 1986; Núñez and Ryvarden, 2000; Roy and De, 1996; Lodge et al., 2004). The morphology or the macrocharacteristics i.e. the outward appearance (fruiting body) were studied carefully and compared or expressed through appropriate photographs and literatures from books and journals (Ian et al., 2003; Jordan, 1993; Osemwegie and Okhuoya, 2009; Osemwegie et al., 2010; Roda, 2010; Scott, 2006; Natarajan and Kolandavelu, 1998; Rattan, 
1977). For microscopic study, thin sections of dried specimens are taken with the help of a sharp razor blade and were mounted in 3\% $\mathrm{KOH}$ solution and stained in Lactophenol or $60 \%$ lactic acid + cotton blue. Spore print of the collected specimens was taken by cutting off the cap and placing it in a piece of white paper (Surcek, 1988).

\section{Diversity indices}

Using standard protocols, diversity indices such as Simpson and Shannon-Weiner diversity indices were used Simpson (1949), Shannon-Wiener (1949).

The Pielous measure of species evenness was estimated Pielou (1966). Species richness was measured using Menhincik's (1964) and Margalef's richness index (1958).

\section{Results and Discussion}

A total of 46 species were identified from both the study sites, 42 belonging to the phylum Basidiomycota and 4 belong to Ascomycota, 13 families and 26 genera. It was observed that a total of 21 species were common to both the forests whereas 19 species were found only found in Hmuifang forest and 6 species was present only in Tanhril forest (Table 1 and Fig. 2).

Polyporaceae is the dominant family (Fig. 1) and Microporus xanthopus represents the most abundant species in both the study sites with species number of 56 and 76 in Hmuifang and Tanhril forests respectively (Table 2).

Shannon-Wiener's diversity index of fungal species was found to be 3.31in Hmuifang forest and 2.99 in Tanhril forest; Simpson shows 0.95 in Hmuifang and 0.90 Tanhril forest; Menhinick's index shows 1.91 for Hmuifang and 1.22 in Tanhril forest;
Margalef's index shows 6.41 in Hmuifang and 3.98 in Tanhril forest; Pielou's eveness index shows 0.54 in Hmuifang and 0.51 in Tanhril forest (Table 3) respectively. Most of the fleshy, jelly and gilled wood rotting fungi like Coprinellus dessimentus, Fistulina hepatica, Lentinus edodes, Tremella fuciformis, T. mesenterica, were recorded in the rainy seasons as this period is favourable for their production, since there is adequate amount moisture, favourable temperature, relative humidity. While the dry season collection was predominated by the polypores like Daedaleopsis quercina, Microporus xanthopus, Trametes hirsutum, T. trogii, etc., which may be due to their tough and large sized fruiting bodies, and their unique adaptations of surviving for several periods.

Reportedly the diversity of tree species indices are such as tree density (Individual $\mathrm{ha}^{-1}$ ) for Tanhril was 2079 and 1500 for Hmuifang forest; Shannon Weiner Diversity index for Tanhril was 4.32 and Hmuifang was 3.22; Simpson Index For Tanhril 0.98 and Hmuifang forest 0.94; Eveness index for Hmuifang 0.82 and not available for Tanhril forest; Margelef's index $\mathrm{D}_{\mathrm{mn}}$ for Tanhril 14.28 and Hmuifang 8.21 (Table 4). The common tree species found in Hmuifang Reserved Forest are Calophyllum polyanthum, Dipterocarpus retusus, Drypetes indica, Elaeocarpus rugosus, Helicia excels, Lithocarpus xylocarpus, Olea dioica, Machilus gamblei, Quercus floribunda, Symplocos racemosa, Styrax polysperma, Tarennoidea walichii, Wedlendia grandis (Sharma et al., 2017). And the common tree species of Tanhril Forest are Alangium chinense Aporusa octandra, Castanopsis tribuloides, Dendrocalamus longispathus Schima walichii and Wendlandia grandi (Lalchhuanawma, 2008).

It has been observed that the diversity of tree species have a great influence on the species 
richness of wood rotting fungi in a forest community (Egbe et al., 2013).

However, the species diversity of wood rotting fungi was higher in Hmuifang forest than compared to Tanhril forest which may be due to higher altitude, low temperature, high relative humidity, soil moisture content and experiences higher amount of rainfall annually which in turn have a great impact on the type of vegetation.

Also, Hmuifang forest is a community reserved forest and is free from anthropogenic activities, whereas Tanhril forest experiences various kind of anthropogenic disturbances from the ongoing development activities of Mizoram University Campus and collection of the dead wood and logs for fuel-wood by the nearby villagers. Thinning and clear cutting alter the fungal community and can reduce the production of sporocarps and ectomycorrhizae. Rydin et al., (1997) found that habitat loss and some forest management practices in Europe have led to declines in the diversity of fungi and in the presence of rare fungal species. Berg et al., (1994) reported that many fungal species in Swedish forests are threatened by the loss of old trees and declines in coarse woody debris.

Table.1 Species identified from both the sites

\begin{tabular}{|l|l|l|l|}
\hline S.No & $\begin{array}{l}\text { Species present only } \\
\text { at Hmuifang forest }\end{array}$ & $\begin{array}{l}\text { Species present only } \\
\text { at Tanhril Forest }\end{array}$ & $\begin{array}{l}\text { Species present in both } \\
\text { the Sites }\end{array}$ \\
\hline $\mathbf{1}$ & Auricularia cornea & Amauroderma rude & Auricularia auricula-judae \\
\hline $\mathbf{2}$ & Cymatodermata dendriticum & Amauroderma rugosum & Auricularia polytricha \\
\hline $\mathbf{3}$ & Daedaleopsis quercina & Auricularia mesenterica & Coprinellus dessimentus \\
\hline $\mathbf{4}$ & Ganoderma lingzhi & Ganoderma applanatum & Cyathus striatus \\
\hline $\mathbf{5}$ & Laetiporus sulphureus & Ganoderma mizoramense & Daldinia concentrica \\
\hline $\mathbf{6}$ & Lentinula edodes & Lenzites warneirii & Fistulina hepatica \\
\hline $\mathbf{7}$ & Lentinus sajor caju & & Hexagonia tenuis \\
\hline $\mathbf{8}$ & Lenzites elegans & & Lentinus badius \\
\hline $\mathbf{9}$ & Micromphale foetidum & & Marasmius sp. \\
\hline $\mathbf{1 0}$ & Pleurotus ostreatus & & Microporus affinis \\
\hline $\mathbf{1 1}$ & Polyporus alveolaris & & Microporus xanthopus \\
\hline $\mathbf{1 2}$ & Polyporus arcularius & & Mycena sp. \\
\hline $\mathbf{1 3}$ & Polyporus badius & & Schizophyllum commune \\
\hline $\mathbf{1 4}$ & Polyporus dictyopus & & Stereum hirsutum \\
\hline $\mathbf{1 5}$ & Polyporus tenuiculus & & Stereum rugosum \\
\hline $\mathbf{1 6}$ & Pycnoporus sanguineus & & Trametes hirsuta \\
\hline $\mathbf{1 6}$ & Trametes modesta & & Trametes trogii \\
\hline $\mathbf{1 8}$ & Trichaptum biforme & & Tremella fuciformis \\
\hline $\mathbf{1 9}$ & Xylaria grammica & Tremella mesenterica \\
\hline $\mathbf{2 0}$ & & & Xylaria hypoxylon \\
\hline $\mathbf{2 1}$ & & & Xylaria longipes \\
\hline & & & \\
\hline
\end{tabular}


Table.2 Occurrence of species in both the sites and collecting season

\begin{tabular}{|c|c|c|c|c|c|}
\hline \multicolumn{3}{|c|}{ Hmuifang Reserve Forest } & \multicolumn{3}{|l|}{ Tanhril forest } \\
\hline Species & $\begin{array}{l}\text { No. of } \\
\text { Species }\end{array}$ & Season & Species & $\begin{array}{l}\text { No. of } \\
\text { Species }\end{array}$ & season \\
\hline $\begin{array}{l}\text { Auricularia auricula- } \\
\text { judae }\end{array}$ & 12 & Rainy & Amauroderma rude & 8 & $\begin{array}{l}\text { Rainy and } \\
\text { dry }\end{array}$ \\
\hline Auricularia cornea & 1 & Rainy & Amauroderma rugosum & 6 & $\begin{array}{l}\text { Rainy and } \\
\text { dry }\end{array}$ \\
\hline $\begin{array}{l}\text { Auricularia } \\
\text { polytricha }\end{array}$ & 8 & Rainy & Auricularia auricularea & 26 & Rainy \\
\hline $\begin{array}{l}\text { Coprinus } \\
\text { dessimentus }\end{array}$ & 25 & Rainy & Auricularia mesenterica & 5 & Rainy \\
\hline Cyathus striatus & 3 & Rainy & Auricularia polytricha & 13 & Rainy \\
\hline $\begin{array}{l}\text { Cymatodermata } \\
\text { dendriticum }\end{array}$ & 3 & Rainy & Coprinellus dessimentus & 38 & Rainy \\
\hline $\begin{array}{l}\text { Daedaleopsis } \\
\text { quercina }\end{array}$ & 6 & Rainy and dry & Cyathus striatus & 9 & Rainy \\
\hline Daldinia concentrica & 5 & Rainy and dry & Daldinia concentrica & 3 & $\begin{array}{l}\text { Rainy and } \\
\text { dry }\end{array}$ \\
\hline Fistulina hepatica & 3 & Rainy & Fistulina hepatica & 2 & Rainy \\
\hline Ganoderma lingzhi & 7 & Rainy and dry & Ganoderma applanatum & 1 & $\begin{array}{l}\text { Rainy and } \\
\text { dry }\end{array}$ \\
\hline Hexagonia tenuis & 27 & Rainy and dry & Hexagonia tenuis & 19 & $\begin{array}{l}\text { Rainy and } \\
\text { dry }\end{array}$ \\
\hline $\begin{array}{l}\text { Laetiporus } \\
\text { sulphureus }\end{array}$ & 1 & Rainy & Lentinus badius & 2 & $\begin{array}{l}\text { Rainy and } \\
\text { dry }\end{array}$ \\
\hline Lentinula edodes & 1 & Rainy & Lenzites warneirii & 2 & $\begin{array}{l}\text { Rainy and } \\
\text { dry }\end{array}$ \\
\hline Lentinus badius & 3 & Rainy and dry & Marasmius sp. & 15 & Rainy \\
\hline Lentinus sajor caju & 3 & Rainy & Microporus affinis & 6 & $\begin{array}{l}\text { Rainy and } \\
\text { dry }\end{array}$ \\
\hline Lenzites elegans & 17 & Rainy and dry & Microporus xanthopus & 76 & $\begin{array}{l}\text { Rainy and } \\
\text { dry }\end{array}$ \\
\hline Marasmius sp. & 1 & Rainy & Mycena sp. & 5 & Rainy \\
\hline $\begin{array}{l}\text { Micromphale } \\
\text { foetidum }\end{array}$ & 8 & Rainy & Schizophyllum commune & 34 & $\begin{array}{l}\text { Rainy and } \\
\text { dry }\end{array}$ \\
\hline Microporus affinis & 12 & Rainy and dry & Stereum hirsutum & 12 & $\begin{array}{l}\text { Rainy and } \\
\text { dry }\end{array}$ \\
\hline $\begin{array}{l}\text { Microporus } \\
\text { xanthopus }\end{array}$ & 56 & Rainy and dry & Stereum rugosum & 12 & $\begin{array}{l}\text { Rainy and } \\
\text { dry }\end{array}$ \\
\hline Mycena sp. & 8 & Rainy & Trametes hirsuta & 23 & $\begin{array}{l}\text { Rainy and } \\
\text { dry }\end{array}$ \\
\hline
\end{tabular}




\begin{tabular}{|l|l|l|l|l|l|}
\hline Pleurotus ostreatus & 1 & Rainy & Trametes trogii & 17 & $\begin{array}{l}\text { Rainy and } \\
\text { dry }\end{array}$ \\
\hline Polyporus alveolaris & 16 & Rainy & Tremella fuciformis & 4 & Rainy \\
\hline Polyporus arcularis & 5 & Rainy & Tremella mesentrica & 3 & Rainy \\
\hline Polyporus badius & 12 & Rainy & Xylaria hypoxylon & 17 & $\begin{array}{l}\text { Rainy and } \\
\text { dry }\end{array}$ \\
\hline Polyporus dictyopus & 15 & Rainy & Xylaria longipes & 14 & $\begin{array}{l}\text { Rainy and } \\
\text { dry }\end{array}$ \\
\hline Polyporus tenuiculus & 8 & Rainy & & & \\
\hline $\begin{array}{l}\text { Pycnoporus } \\
\text { sanguineus }\end{array}$ & 5 & Rainy and dry & & & \\
\hline $\begin{array}{l}\text { Schizophyllum } \\
\text { commune }\end{array}$ & 25 & Rainy and dry & & & \\
\hline $\begin{array}{l}\text { Stereum hirsutum } \\
\text { Stereum rugosum }\end{array}$ & 17 & 2 & Rainy and dry & & \\
\hline Rramates modesta & 12 & Rainy and dry & & & \\
\hline Trametes hirsuta & 21 & Rainy and dry & & \\
\hline Trametes trogii & 6 & Rainy and dry & & & \\
\hline Tremella fuciformis & 3 & Rainy & & \\
\hline Tremelles mesentrica & 6 & Rainy & & \\
\hline Trichaptum biforme & 18 & Rainy and dry & & \\
\hline Xylaria gramica & 24 & Rainy and dry & & \\
\hline Xylaria hypoxylon & 18 & Rainy and dry & & \\
\hline Xylaria longipes & 18 & Rainy and dry & & \\
\hline & & & & \\
\hline
\end{tabular}

Table.3 Species diversity indices of wood rotting fungi from both sites

\begin{tabular}{|l|l|l|l|l|l|}
\hline Sites & Shannon-Weiner & Simpson & Menhinick's & Margelef's & Pielou's eveness \\
\hline Hmuifang & 3.31 & 0.95 & 1.91 & 6.41 & 0.54 \\
\hline Tanhril & 2.99 & 0.90 & 1.22 & 3.98 & 0.51 \\
\hline
\end{tabular}

Table.4 Tree species indices of Hmuifang forest (Sharma et al., 2017) and Tanhril forest (Lalchhuanawma, 2008)

\begin{tabular}{|c|c|c|}
\hline Paramerters & Hmuifang & Tanhril \\
\hline Tree Density(Individual ha ${ }^{-1}$ ) & 1500 & 2079 \\
\hline Shannon Weiner Diversity index & 3.22 & 4.32 \\
\hline Simpson Index & 0.94 & 0.98 \\
\hline Eveness index & 0.82 & -- \\
\hline Margelef's index $D_{m n}$ & 8.21 & 14.28 \\
\hline
\end{tabular}


Fig.1 Representative families and number of species present from Hmuifang and Tanhril forest

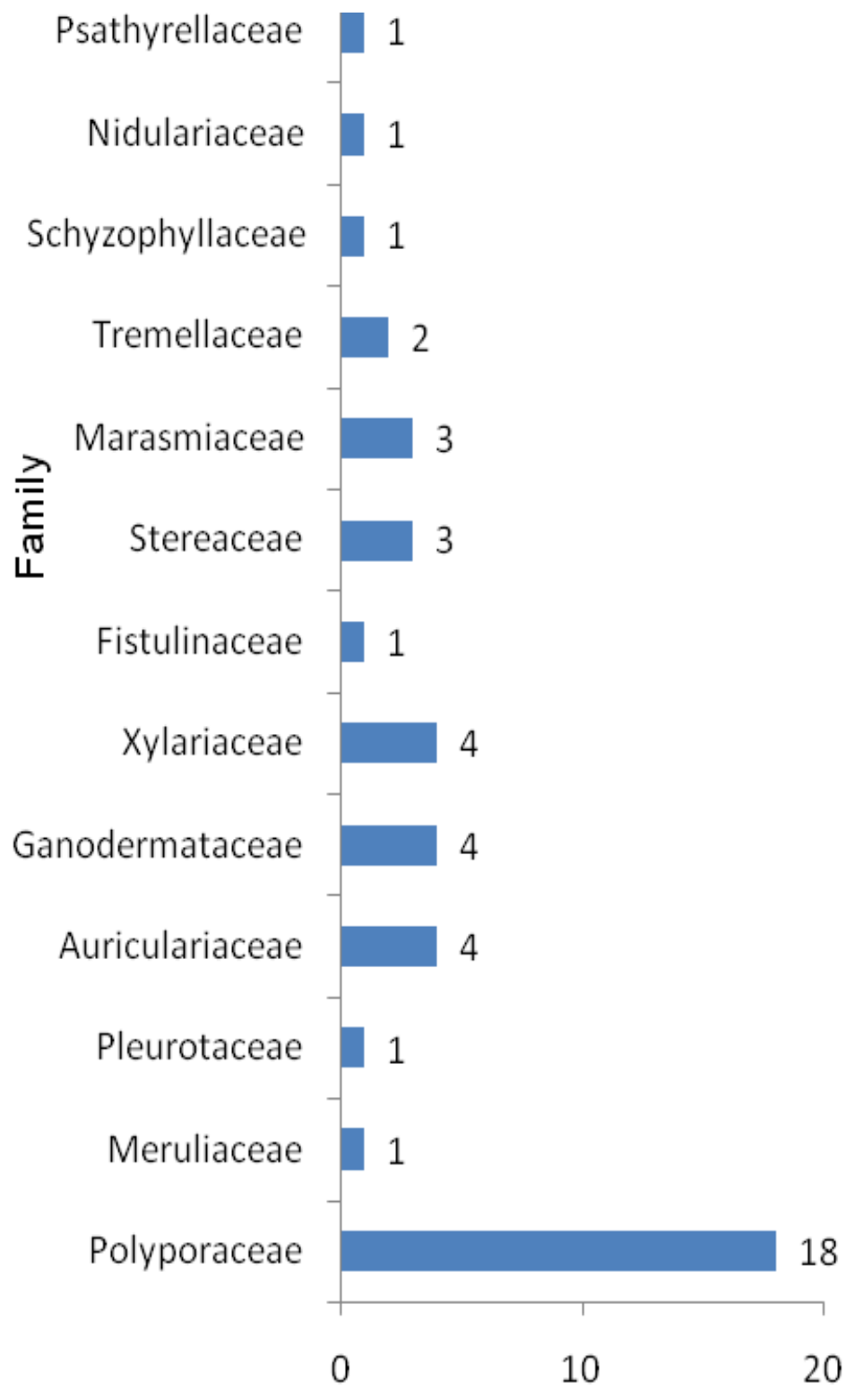

No.of Species 
Fig.2 Some of the common fungal species

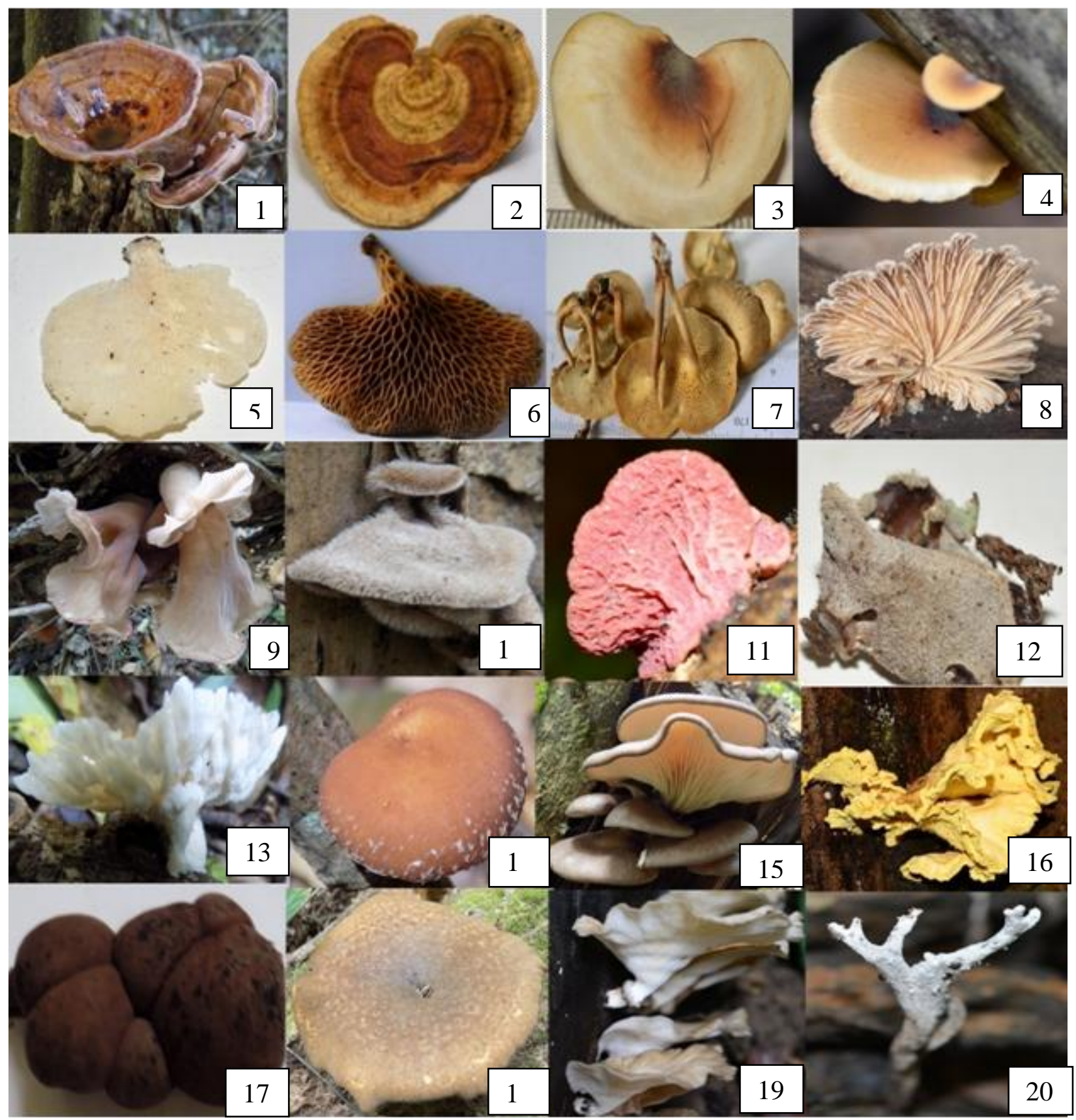

1. Microporus xanthopus 2. M.affinis 3. Polyporus dictyopus 4. P. badius 5. P. tenuiculus 6. P. alveolaris

7. P. arcularis 8. Schizophyllum commune 9. Auricularia auricularae 10. A. polytricha 11. A. delicate 12. A. cornea. 13. Cymatodermata dentriticum 14. Lentinula edodes 15. Pleurotus ostreatus 16. Laetiporus sulphureus 17. Daldinia concentrica 18.L.badius 19. L. sajor-caju 20.Xylaria hypoxylon

The importance of presence of old dying trees and fallen logs for presence of wood rotting fungi is recognized from studies where it was found that there is a correlation between the decay of the wood and the species of fungi recorded as sporocarps (Hoiland and Bendiksen, 1997; Lindblad, 1998; Renvall, 1994). The influence of removal of both the 
live and dead substrata for the wood rotting fungal species may be the reason for the fewer number of species from Tanhril forest.

\section{References}

Berg, A., Ehnstrom, B., Gustafsson, L., Hallingback. T., Jonsel, LM., Weslien, J. 1994. Threatened plant, animal, and fungus species in Swedish forests: distribution and habitat associations. Conservation Biology. 8(3): 718-731.

Bisht, N.S. 2011. Wood decaying fungi of Mizoram. Department of Environment and Forest, Govt of India. 196 pp.

Douanla-Meli, C., Ryvarden, L., Langer, E. 2007. 'Studies of tropical African pore fungi (Basidiomycota, Aphyllophorales): three new species from Cameroon' Nova Hedwigia 84, 3-4 409-420.

Egbe, E.A., Tonjock, R.K., Ebai, M.T., Nji, T. and Afui, M.M. 2013. Diversity and distribution of macrofungi (mushrooms) in the Mount Cameroon Region. Journal of Ecology and the Natural Environment. Vol. 5(10), pp. 318-334.

Gilbertson, R.L., Ryvarden, L. 1986. North American Polypores. Fungiflora, Oslo.

Hawksworth, L.D. 2004. Fungal diversity and its implications for genetic resource collections. Studies in Mycol 50:9-18.

Hawksworth. L.D. 2001. The magnitude of fungal diversity: the 1.5 million species estimate revisited. Mycolog Res. 105:1422-1432.

Hoiland, K., Bendiksen, E. 1997. Biodiversity of wood inhabiting fungi in a boreal coniferous forest in Sor-Trendeiag County, central Norway. Nord. J. Bot., 16:643-659.

Ian, R.H., Steven, L.S., Peter, K.B., Wang, Y., Anthony, L.J.C. 2003. Edible and poisonous mushrooms of the world. Published by New Zealand Institute for Crop and Food Research Limited, Private Bag 4704 Christchurch, New Zealand. 371p

Jordan, M. 1993. Edible mushrooms and other fungi. Published by Blandford, A Cassell imprint Villiers House, 41-47 Strand London, 124pp.

Lalchhuanawma. 2008. Ecological studies on plant diversity and productivity of herbaceous species in Mizoram university campus at Tanhril, Aizawl, Mizoram (n.e. India). Ph.D. Thesis

Lindblad, I. 1998. Wood-inhabiting fungi on fallen logs of Norway spruce: relations to forest management and substrate quality. NordJBot., 18: 243-254.

Lodge, D.J., Ammirati, J., O'Dell, T.E., and Mueller, G.M. 2004. Collecting and describing macrofungi: Inventory and Monitoring Methods. In G. M. Mueller, G. Bills, \& M. S. Foster (Eds.), Biodiversity of Fungi: Inventory and Monitoring Methods (pp. 128-158). San Diego, CA: Elsevier Academic Press.

Lonsdale, D., Pautasso, M., and Holdenrieder, O. 2008. Wood-decaying fungi in the forest: conservation needs and management options. European Journal of Forest Research, 127(1): 1-22 pp.

Margalef, R. 1958. Temporal succession and spatial heterogeneity in phytoplankton. In: Perspectives in Marine biology, BuzzatiTraverso (ed.), Univ. Calif. Press, Berkeley, pp. 323-347.

Meenakshisundaram, M., and Bharathiraja, C. 2013. Isolation of wood rot fungi from Maruthamalai hills Western Ghats area of south India, Int.J.Curr.Microbiol.App.Sci., 2(9), 215-218pp.

Menhinick, E.F. 1964. A Comparison of Some Species-Individuals Diversity Indices Applied to Samples of Field Insects, Ecology, Vol. 45, No. 4, pp. 859-861.

Natarajan, K., and Kolandavelu, K. 1998. Resupinate Aphyllophorales of Tamil Nadu, India. Centre for advanced study in Botany, University of Madras, 133pp.

Núñez, M., and Ryvarden, L. 2000. East Asian Polypores. Fungiflora, Oslo.

Ottosson, E. 2013. Succession of Wood-inhabiting Fungal Communities; Diversity and Species Interactions During the Decomposition of Norway Spruce.

Osemwegie, O.O., Okhuoya, J.A. 2009. Diversity of macrofungi in oil palm agroforests of Edo State, Nigeria. J. Biol. Sci. 9(6):584593.

Osemwegie, O.O., Okhuoya, J.A., Oghenekaro, A.O., Evueh, G.A. 2010. Macrofungi community in rubber plantations and a 
forest of Edo State, Nigeria. J. Appl. Sci. 10:391-398.

Pielou, E.C. 1966. The measurement of diversity in different types of biological collections. J. Theoret. Biol., 13: 131-144.

Prasher, I.B. 2015. Wood-rotting non-gilled Agaricomycetes of Himalayas: Fungal Diversity Research Series,Springer,Netherlands,67-68pp.

Rattan, S.S. 1977. The Resupinate Aphyllophorales of the North Western Himalayas. J. Cramer, In der A.R. K.G. FL9490 Vaduz, Germany, 427pp.

Renvall, P. 1994. Community structure and dynamics of wood-rotting Basidiomycetes on decomposing conifer trunks in northern Finland. Karstenia 35:1-51.

Roda, F.A. 2010. Survey of Macrofungi (including Truffles) in Qatar KBM Jr of Biol 1:26-29.

Roy, A., De, A.B. 1998. Polyporaceae of India. International Book distributors. Dehradun.

Rydin, H., Kiekmann, M., Hallingbäck, T. 1997. Biological characteristics, habitat associations, and distribution of macrofungi in Sweden. Conservation Biology. 11: 628640.

Schmit, J.P., Murphy, J.F., Mueller, G.M. 1999. Macrofungal diversity of a temperate oak forest: A test of species richness estimators, Canadian Journal of Botany 77(7):10141027

Scott, T.B. 2006. A Preliminary Checklist of Arizona Macrofungi. CANOTIA 2:47-78.

Shannon, C.E. and Wiener, W. 1949. The mathematical theory of communication. Urbana, University of Illinois Press, 177 p.
Sharma, S.B., Singh, N.S., and Lalruatfela, R. 2018. Tree diversity and carbon stocks of Hmuifang forest, Mizoram International Journal of Research in BioSciences Volume 7 Issue 1, pp. (87-99),

Simpson, E.H. 1949. Measurement of diversity. Nature, 163, 688. doi:10.1038/163688a0

Surcek, M.1988. The illustrated book of Mushrooms and Fungi. Octopus Book, London.

Zothanmawia, R., Vanlalpeka, Vanlalhruaii, R., Lalruatsanga, H., Thapa, H.S., Vanlalhluna, P.C. 2016. Diversity of wood decaying fungi in Pacchunga University College Campus, Aizawl, Mizoram, ENVIS Centre: Mizoram; Status of Environment and Related Issues, Biological Diversity in Mizoram

Zothanzama, J. 2011. Wood Rotting Fungi of Mizoram. In H. Lalramnghinglova and F. Lalnunmawia (eds). Forest Resources of Mizoram:Conservation and Management. Department of Environmental Science, Mizoram University and Regional Centre, National Afforestation and Ecodevelopment Board; North Eastern Hill University. 345: 326-345.s

Zothanzama, J. and Lalrinawmi. 2015. Wild Edible Mushroom of Mizoram. In Karlyn Eckman and Laltanpuii Ralte,; Integrated Land Use Management in the Eastern Himalayas. Akansha Publishing House, New Delhi - 110002.171-181pp.

Zothanzama, J, Josiah, M.C.V., Robert, A.B., and Benjamin, W.H. 2017. Ganoderma mizoramense, Persoonia - Volume 38,pp 326-327.

\section{How to cite this article:}

Josiah M.C. Vabeikhokhei, Zohmangaiha, John Zothanzama and Lalrinawmi, H. 2019. Diversity Study of Wood Rotting Fungi from Two different Forests in Mizoram, India. Int.J.Curr.Microbiol.App.Sci. 8(04): 2775-2785. doi: https://doi.org/10.20546/ijcmas.2019.804.323 